\title{
19: 48451113-47443542
}

National Cancer Institute

\section{Source}

National Cancer Institute. 19:48451113-47443542. NCI Thesaurus. Code C42214.

Physical location of ERF_Gene 